University of Nebraska - Lincoln

DigitalCommons@University of Nebraska - Lincoln

9-1997

\title{
Selective Feeding by Phyllostomid Fruit Bats in a Subtropical Montane Cloud Forest
}

\author{
David Herníndez-Conrique \\ Universidad de Guadalajara, Apartado Postal 64, Autlín, Jalisco 48900, México \\ Luis Iñiguez-Dávalos \\ Universidad de Guadalajara, Apartado Postal 64, Autlín, Jalisco 48900, México \\ Jay F. Storz \\ University of Nebraska - Lincoln, jstorz2@unl.edu
}

Follow this and additional works at: https://digitalcommons.unl.edu/bioscistorz

Part of the Genetics and Genomics Commons

Herníndez-Conrique, David; Iñiguez-Dávalos, Luis; and Storz, Jay F., "Selective Feeding by Phyllostomid Fruit Bats in a Subtropical Montane Cloud Forest" (1997). Jay F. Storz Publications. 25.

https://digitalcommons.unl.edu/bioscistorz/25

This Article is brought to you for free and open access by the Papers in the Biological Sciences at DigitalCommons@University of Nebraska - Lincoln. It has been accepted for inclusion in Jay F. Storz Publications by an authorized administrator of DigitalCommons@University of Nebraska - Lincoln. 
Published in Biotropica 29:3 (September 1997) , 376-379; doi 10.1111/j.1744-7429.1997.tb00441.x

Copyright (C) 1997 Association for Tropical Biology and Conservation Inc.; published by John Wiley \& Sons. Used by permission. http://www3.interscience.wiley.com/journal/118501466/home

Submitted February 23, 1995; revised and accepted January 26, 1996.

\title{
Selective Feeding by Phyllostomid Fruit Bats in a Subtropical Montane Cloud Forest
}

\author{
David Herníndez-Conrique, ${ }^{1}$ Luis I. Iñiguez-Dávalos, ${ }^{1}$ and Jay F. Storz ${ }^{2}$ \\ ${ }^{1}$ Instituto Manantlín de Ecología y Conservación de la Biodiversidad, Centro Universitario Costa Sur, \\ Universidad de Guadalajara, Apartado Postal 64, Autlín, Jalisco 48900, México. \\ ${ }^{2}$ Department of Biology, Boston University, Boston, MA 02215, U.S.A.
}

Keywords: Dermanura, fruit bats, frugivory, México, montane cloud forest, Phyllostomidae, selective feeding, seed dispersal, Sturnira

Phyllostomid bats eat the fruits and disperse the seeds of a wide variety of neotropical plant species, particularly those typical of early successional stages (Fleming \& Heithaus 1981, Heithaus 1982, Orozco-Segovia et al. 1985). In assessing the effects of frugivorous animals on plant populations and vice-versa, it is important to determine whether the animals are selective in the types of fruit they eat, or whether the proportional abundance of different fruit species in their diets simply reflects availability in the environment. The purpose of this study was to test experimentally the hypothesis that two common phyllostomid species, Sturnira ludovici and Dermanura tolteca (= Artibeus toltecus), feed selectively in the subtropical montane cloud forest of western México.

Feeding selectivity of plant-visiting animals can be measured at several ecological scales. At the community level, fruit bats and other taxonomic guilds of vertebrate frugivores exploit only a limited subset of the available fruit resource base (Heithaus et al. 1975, Janson 1983, Gautier-Hion et al. 1985). At this level, the phyllostomid bats in our study area appear to feed selectively, insofar as seeds identified from the feces of mist-netted bats represent only a fraction of the potentially available cloud forest plant species. Fruits of second-growth shrubs accounted for the overwhelming majority of 117 fecal samples obtained from S. ludovici captured throughout the yearly cycle, 1991-1993. In particular, fruits of two common groundstory shrubs, Solanum nigricans and S. aphyodendron (Solanaceae), accounted for 40 and 43 percent of all samples, respectively. Fruits of Conostegia volcanalis (Melastomataceae), a subcanopy-level tree common in moist drainages, accounted for 7 percent. Of 29 fecal samples obtained from $D$. tolteca captured during this same time period, fruits of S. nigricans and S. aphyodendron accounted for 21 and 42 percent of all samples, respectively, whereas fruits of $C$. volcanalis accounted for 38 percent. All fecal samples contained seeds of only one species per sample. The relative importance of these three plants as fruit resources for bats is corroborated by rates of nocturnal fruit-removal from plants monitored in the field (Schöndube-F. 1994). Here we report the results of feeding experiments designed to test whether cloud forest bats feed selectively among a limited array of six fruit species actually known or suspected of being included in their diets.

Compared to other fruits in its diet, S. ludovici handles and digests S. nigricans fruits more efficiently, and extracts more metabolizable energy per fruit. Solanum nigricans fruits are also highest in sugar and protein content (Schöndube-F. 1994). Because the overall ease of handling, digestibility, and nutritional quality of fruit are known to influence the diet choice of frugivores (Moermond \& Denslow 1985, Bonaccorso \& Gush 1987), we predicted that captive S. ludovici would feed selectively on S. nigricans fruits.

In a premontane cloud forest in Costa Rica, both S. ludovici and D. tolteca fed on the fruits of secondgrowth shrubs, although $D$. tolteca specialized on the fruit crops of canopy level trees during seasonal peaks in fruit abundance (Dinerstein 1986). Under the assumption that patterns of habitat use and feeding behavior are similar in our study area, we predicted that captive $D$. tolteca would feed selectively on the fruits of $C$. volcanalis. 
This study took place at the Las Joyas Scientific Station, Sierra de Manantlán Biosphere Reserve, Jalisco, México. For details on the natural history and management of the site see Jardel (1992). Las Joyas (1,900 m) covers an area of 1,245 ha in the Sierra de Manantlán mountain range in western México, $40 \mathrm{~km}$ from the Pacific coast. This area is characterized by high topographic diversity and includes five principal vegetation types: pine and pine-oak forests (roughly $54 \%$ of total area), cloud forest $(25 \%)$, second growth (16\%), oak forest $(4 \%)$, and riparian forest (1\%). The patchy distribution of these habitats at Las Joyas is due in part to a long history of human disturbance predating its current protected status. Past sources of disturbance include agriculture, cattle grazing, timber harvesting, and fire. A distinct neotropical-nearctic mix of floral and faunal elements reflects the subtropical nature of the area, and is most pronounced in the cloud forest habitat. Of the 12 species of plant-visiting bats known to occur at Las Joyas, S. ludovici and D. tolteca respectively account for 50\% and 25\% of all captured individuals (Iñiguez-Dávalos 1993). In the same area the plants S. nigricans, S. aphyodendron, and C. volcanalis achieve densities of 1866, 21, and 180 individuals/ha, respectively (Muñoz-Mendoza 1992).

We conducted feeding experiments with captive bats from May to September 1993 and September to October 1994. Experiments were conducted at uniform intervals throughout each study period and the choice of fruit species used in each trial was dictated by availability. We captured experimental animals in the cloud forest with mist nets set in flyways. We identified individual bats to species, sex, adult or juvenile age class, and reproductive condition, and marked each animal on the crown of the head with a felt-tip marker. Experimental trials were conducted either the night of capture, or the following night, in which case captive animals were initially fed banana, papaya, and melon. Individual bats were not used for more than one choicetrial. We did not use juveniles nor palpably pregnant or lactating females in the experiments. Data from both sexes were pooled.

In each choice-trial, a single bat was released into a $2 \times 2 \times 4$ m outdoor flight cage constructed of nylon mesh netting covering a frame of metal tubes set over natural soil substrate. Bats were presented with 15 ripe fruits of each of two plant species and allowed to feed for two hours. The fruits in each experiment were placed on wires set $25 \mathrm{~cm}$ apart and hung alternately by species in a symmetrical $6 \times 5$ vertical grid on one wall of the cage. We collected ripe fruits at or near netting sites the afternoon of the experiments.

We conducted a total of 68 fruit choice-trials, involving fruits of six potentially bat-dispersed plant species in seven pair-wise combinations for $S$. ludovici $(N=48$ trials), five for $D$. tolteca $(N=18)$, and one for $S$. lilium $(N=2)$, another species present in our study area. We considered feeding to be selective, as opposed to opportunistic, when the proportion of fruit species eaten was higher than expected by chance ( $c f$. Fleming 1986). According to this criterion, bats exhibited selective feeding in five of the pair-wise combinations for which there was a sufficient number of replicates for statistical analysis (Table 1). Clear trends were apparent in smaller samples as well.

As predicted, D. tolteca selected C. volcanalis over all the other fruit species offered. Sturnira ludovici selected C. volcanalis, S. aphyodendron, and S. nigricans over the remaining species, but fed randomly within this preferred set of fruits. This runs counter to our prediction of selective feeding on S. nigricans. The small sample for S. lilium suggested selection of $C$. volcanalis over $S$. aphyodendron (13/2). These data agree with observations from a Costa Rican premontane cloud forest, where free-ranging $D$. tolteca fed more selectively than S. ludovici on a monthly basis (Dinerstein 1986). At this same site, D. tolteca primarily visited mature forest trees during the late wet season, whereas S. ludovici was associated year-round with second-growth shrubs such as Solanum and Piper. Fleming (1986) also considered Solanum a core taxon for S. lilium in the Costa Rican tropical dry forest.

The feeding selectivity of captive bats in our experiments suggests that $C$. volcanalis represents an important fruit resource base for the apparently more specialized $D$. tolteca, whereas the more generalized diet of $S$. ludovici includes a higher proportion of Solanum fruits. The fact that Solanum fruits are higher in nutritional quality than those of C. volcanalis with respect to sugar and protein content (Schöndube-F. 1994) suggests an explanation for the differences in diet breadth between the two bat species. Fleming (1986) suggested that bats eating nutritionally high-quality fruit such as Solanum generally have broader diets than those eating abundant, but low quality fruits. This is because dietary specialization is only possible with high fecundity plants which produce a reliable (although possibly low quality) food source throughout a long fruiting season.

If $S$. nigricans fruits are of generally higher nutritional quality than the others, why are they not consistently selected by bats over the rest? Indeed, feeding experiments in the Costa Rican tropical dry forest with captive Carollia perspicillata (a phyllostomid ecologically similar to S. ludovici) showed that this species fed selectively on high-protein, low-fiber fruits (Fleming 1988). However, ecological factors such as spatio-tempo- 
Table 1. Pairwise selectivity of fruits by $S$. ludovici ( $N=48$ choice-trials) and $D$. tolteca $(N=18)$ expressed as proportions of total fruits eaten (number in parentheses). Results from individual choice-trials are pooled. Plant species are Conostegia volcanalis (CV), Solanum aphyodendron (SA), S. nigricans (SN), S. appendiculatum (SAp), Dendropanax arboreus (DA) and Lycianthes moziniana (M).

\begin{tabular}{|c|c|c|c|}
\hline \multicolumn{4}{|c|}{ Preference for } \\
\hline Over & $\mathrm{CV}$ & SA & $\mathrm{SN}$ \\
\hline \multicolumn{4}{|c|}{ Sturnira ludovici } \\
\hline SA & $\begin{array}{l}0.50 \\
(88)\end{array}$ & - & $\begin{array}{l}0.59 \\
(63)\end{array}$ \\
\hline SN & $\begin{array}{l}0.55 \\
(75)\end{array}$ & - & - \\
\hline SAp & - & $\begin{array}{l}1.0^{\mathrm{a}} \\
(22)\end{array}$ & $\begin{array}{l}1.0^{\mathrm{a}} \\
(19)\end{array}$ \\
\hline DA & $\begin{array}{l}0.97^{a} \\
(41)\end{array}$ & - & $\begin{array}{l}0.98^{\mathrm{a}} \\
(61)\end{array}$ \\
\hline \multicolumn{4}{|c|}{ Dermanura tolteca } \\
\hline SA & $\begin{array}{l}0.94^{\mathrm{a}} \\
(49)\end{array}$ & - & - \\
\hline SN & $\begin{array}{l}0.73 \\
(37)\end{array}$ & $\begin{array}{l}1.0 \\
(14)\end{array}$ & - \\
\hline DA & - & - & $\begin{array}{l}1.0 \\
(3)\end{array}$ \\
\hline LM & $\begin{array}{l}0.95 \\
(20)\end{array}$ & - & - \\
\hline
\end{tabular}

a Selectivity $=$ proportion of fruit species deviates from chance expectations at $P<0.05$ using Kruskall-Wallis one-way analysis of ranks, $\mathrm{df}=1$.

ral availability of different fruits and dietary specializations of bat species may often override strictly nutritional considerations influencing food choice (Fleming 1981, 1988). For example, Bonaccorso and Gush (1987) found that captive phyllostomid bats with specialized feeding habits often preferred low nutrient-content dietary staples over higher quality fruits rarely eaten by free-ranging individuals. This seems a likely explanation for the preference of $D$. tolteca for $C$. volcanalis fruits over the higher quality $S$. nigricans fruits in our experiments. Because feeding preferences of captive bats are likely influenced by fruit availability in the environment during the test-period, our selection of fruits for choice-trials (though also influenced by spatiotemporal availability) is a potential source of bias.

The two bat species tested in these feeding experiments apparently differ in their degree of dietary specialization, as $D$. tolteca fed selectively on a single plant taxon while $S$. ludovici fed randomly within a subset of preferred taxa. Field data on free-ranging bats are needed to determine how different feeding strategies influence nightly and seasonal patterns of movement between feeding areas. More research from a botanical perspective is needed to determine how such differences in bat foraging movements affect the quality of seed dispersal services provided. The fact that in the field fruits of C. volcanalis, S. nigricans, and S. aphyodendron are removed almost exclusively at night (Schöndube-F. 1994) suggests that these bats are important seed dispersers and likely exert a strong influence on the reproductive success of their food plants.

We thank T. H. Fleming, V. Sánchez-Cordero, H. Arita, R. Medallín, R. K. LaVal, and T. H. Kunz for comments on this note and the personnel at Las Joyas Scientific Station and IMECBIO for support in the field. This work was funded in part by a scholarship to LIID from the Academic Interchange Program at the Universidad Nacional Autónoma de México. 


\section{References}

Bonaccorso, F. J., and T. J. Gush. 1987. Feeding behavior and foraging strategies of captive phyllostomid fruit bats: an experimental study. J. Anim. Ecol. 56: 907-920.

Dinerstein, E. 1986. Reproductive ecology of fruit bats and the seasonality of fruit production in a Costa Rican cloud forest. Biotropica 18: 307-318.

Fleming, T. H. 1981. Fecundity, fruiting pattern, and seed dispersal in Piper amalago (Piperaceae), a bat-dispersed tropical shrub. Oecologia 51: 42-46.

- 1986. Opportunism versus specialization: the evolution of feeding strategies in frugivorous bats. In A. Estrada and T. H. Fleming (Eds.). Frugivores and seed dispersal, pp. 105-116. Dr. W. Junk Publishers, Dordrecht, The Netherlands.

- 1988. The short-tailed fruit bat: a study in plant-animal interactions. University of Chicago Press, Chicago. 13 (Suppl.): 45-53.

Gautier-Hion, A., J.-M. Duplantier, R. Quris, F. Feer, C. Sourd, J.-P. Decoux, G. Dubost, L. Emmons, C. Erard, P. Hecketsweiler, A. Moungazi, C. Roussilhon, and J.-M. Thiollay. 1985. Fruit characteristics as a basis of fruit choice and seed dispersal in a tropical forest vertebrate community. Oecologia 65: 324-337.

Heithaus, E. R. 1982. Coevolution between bats and plants. In T. H. Kunz (Ed.). Ecology of bats, pp. 327-367. Plenum Press, New York.

- T. H. Fleming, and P. A. Opler. 1975. Foraging patterns and resource utilization in seven species of bats in a seasonal tropical forest. Ecology 56: 841-854.

Iñiguez-Dávalos, L. I. 1993. Patrones ecológicos en la communidad de murciélagos de la Sierra de Manantlán, Jalisco. In R. A. Medellín and G. Ceballos (Eds.). Avances en el estudio de los mamíferos de México, pp. 355-370. Asociación Mexicana de Mastozoología, A. C., Mexico City.

Janson, C. H. 1983. Adaptation of fruit morphology to dispersal agents in a neotropical forest. Science 219: 187-189.

Jardel, E. J. 1992. Estrategia para la conservación de la Reserva de la Biosfera Sierra de Manantlán. Editorial Universidad de Guadalajara. Guadalajara. 315 pp.

Moermond, T. C., and J. S. Denslow. 1985. Neotropical avian frugivores: patterns of behavior, morphology, and nutrition, with consequences for fruit selection. In P. A. Buckley, M. S. Foster, E. S. Morton. R. S. Ridgely, and N. G. Smith (Eds.). Neotropical Ornithology, pp. 865-897. Ornith. Monogr. 36.

Muñoz-Mendoza, M. E. 1992. Distribución de especies arboreas del bosque mesófilo de montaña de la Biosfera Sierra de Manantlán. Tesis de licenciatura, Universidad de Guadalajara, Guadalajara.

Orozco-Segoma, A., C. Vazquez-Yanes, M. A. Armella, and N. Correa. 1985. Interacciones entre una población de murciélagos de la especie Artibeus jamaicensis y la vegetación delárea circundante, en la región de Los Tuxtlas, Veracruz. In A. Gomez-Pompa and S. Del Amo R. (Eds.). Investigaciones sobre la regeneración de selvas altas en Veracruz, México, pp. 365-377. Instituto Nacional de Investigaciones Sobre Recursos Bióticos, Xalapa.

Schöndube-F., J. E. 1994. Interacciones entre Sturnira ludovici (Chiroptera: Phyllostomidae) y plantas del bosque mesófilo de montaña en la Sierra de Manantlán, Jalisco, México: una aproximación mutualista. Tesis de licenciatura, Universidad de Guadalajara, Guadalajara. 